\title{
Assessment of water quality of degraded anthropogenic reservoirs situated in the area of the former Rozbark Coal Mine in Bytom
}

\author{
Łukasz Piotr Gawor, Sylwia Lutyńska
}

Silesian University of Technology, Faculty of Mining and Geology, Institute of Applied Geology; ul. Akademicka 2a, 44-100 Gliwice,Poland; e-mail:lukasz.gawor@polsl.pl,sylwia.lutynska@polsl.pl

(C) 2015 Authors. This is an open access publication, which can be used, distributed and reproduced in any medium according to the Creative Commons CC-BY 4.0 License requiring that the original work has been properly cited.

Received: 21 November 2014; accepted: 15 October 2015

\begin{abstract}
In this paper, the degree of contamination of water was determined from anthropogenic reservoirs, located in the area of former coal mine Rozbark in Bytom. The physicochemical analysis of water indicated a high degree of anthropopression. In all analyzed reservoirs, permissible concentrations of chlorides and sulphates were exceeded. In the majority of them, the values of electrical conductivity and total suspended solids were also exceeded. In order to determine the transformation of surface water contamination, there was a comparison of archival data of water quality and laboratory tests performed after five years. Comparative analysis shows that in the last five years, there has been no improvement in the quality of the analyzed surface waters. In fact deterioration of the quality was noticeable.
\end{abstract}

Keywords: degraded anthropogenic reservoirs, surface water quality, reclamation

\section{INTRODUCTION}

The degraded subsidence post-mining area in Bytom, Rozbark is an example of an interesting and natural valuable terrain, showing significant influence of anthropogenic pressure. The storage of communal and mining wastes of the land's surface and surface water contamination belong to the most important environmental problems in the described area. Coal, as well as $\mathrm{Zn}$ and $\mathrm{Pb}$ ores exploitation resulted in subsidence, collapses and construction of dumps, which led to the disturbance of natural water circulation. A particular characteristic of the area is the diversity of different anthropogenic landforms and types of wastes.
A complex reclamation of the described terrain was done on the area of 7 ha. In the first stage, the wastes gathered in the ground surface were removed. Thereafter, steps of reclamation and management in the way of a park and recreation area were taken. A landscape architecture project covered $\sim 5.6$ ha of ground surface, which made it possible to complete a complex reclamation of the terrain, with all the necessary stages (technical reclamation, biological reclamation, assembling full technical infrastructure and an indispensable communication network). The greenery designed was based on the existing forest stand. Biological reclamation on the part of the waste dump was managed by creating sewing grass mixtures. In the reclamation area, four sightseeing terraces and 
architectural objects were built (Studium wykonalności... 2009).

In the area connected with the mining activity, surface and groundwater chemistry was formed as a result of mine drainage, which begins from the intensive weathering of waste dumps. Finally, this process may lead to heavy acidification and increase the concentration of sulfates and metals in the water. Mine drainage is observed especially in ore, coal mine and waste dumps, where waste rocks are exposed to atmospheric factors. In Poland, this problem occurs eg. in coal mines, which are located in the southwestern part of the Upper Silesian Coal Basin (Pluta 2004), in the eastern part of the Arch of Muskau (Labus \& Skoczyńska 2013), in the Częstochowa region (Razowska 2001) and in the vicinity of the mine waste dumps (Twardowska et al. 1988, Szczepańska 1990). In the area of former coal mine Rozbark in Bytom, the impact of mine drainage on the water environment is also observed.

\section{STUDY AREA}

The post-mining degraded area of the former coal mine Rozbark in Bytom is situated in the northern part of the Silesian Upland (Wyżyna Śląs$\mathrm{ka}$ ), in the meso-region of the Katowice Upland (Wyżyna Katowicka) and in the Bytom-Katowice Plateau (Płaskowyż Bytomsko-Katowicki). These areas represent a terrain with relative elevations of 260-270 $\mathrm{m}$ a.s.l. A significant influence on the morphology of the land was derived from the mining exploitation (mining subsidences, coal mining waste dumps), as well as the exploitation of $\mathrm{Zn}$ and $\mathrm{Pb}$ ores (Kondracki 2000).

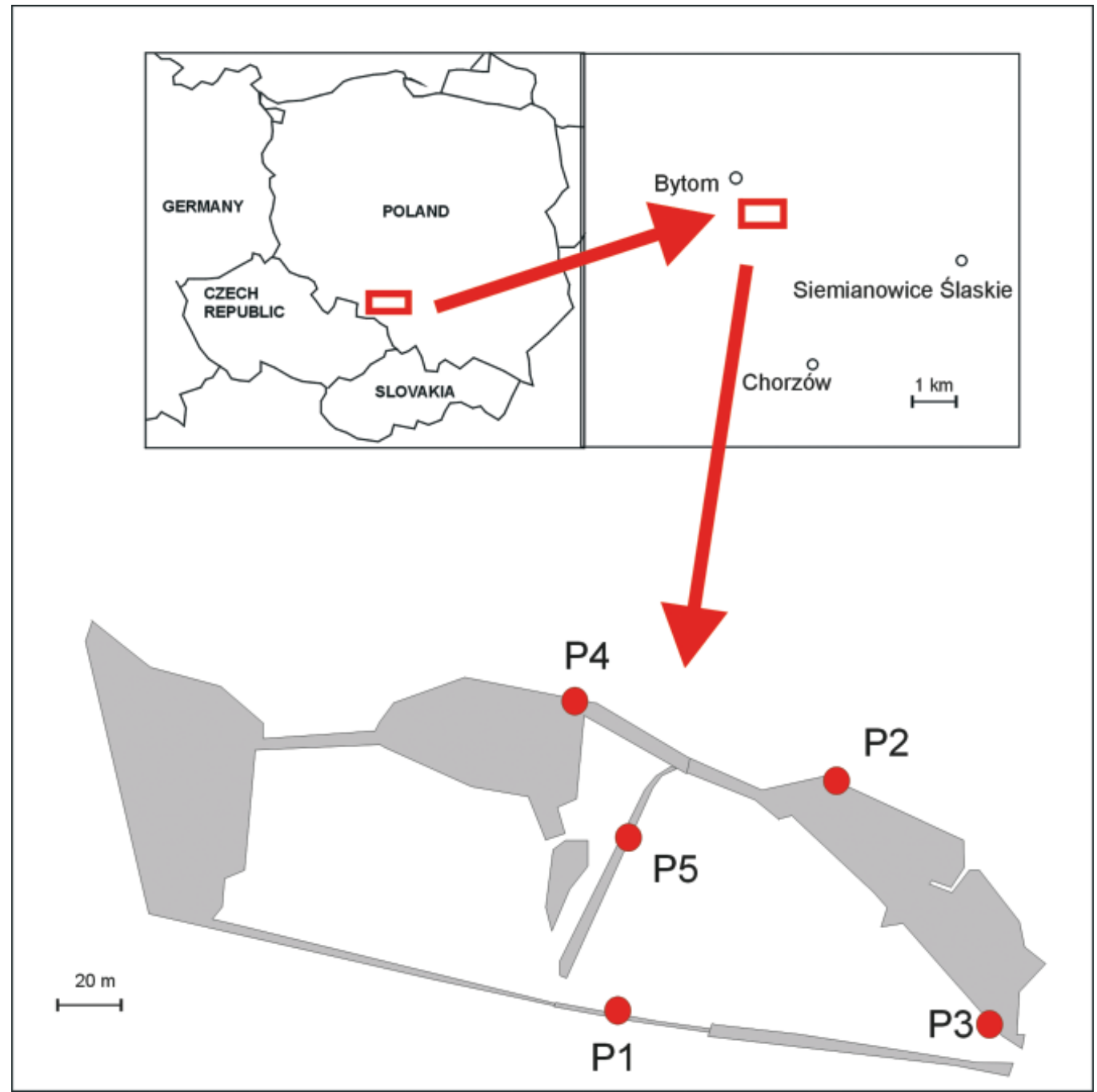

Fig. 1. Location of the study area and sampling points: P1-P5 - sampling points 
The study area is situated in the limits of intensive underground mining activity. As a consequence of over 130 years of hard coal exploitation, the transformation of the natural relief and origination of anthropogenic landforms occurred. Some of these landforms are very old. Waste dumps may be recognized on topographic maps from the beginning of the $20^{\text {th }}$ century. It may be concluded, that the degradation of the terrain has been occurring for over 100 years. Mining subsidences in the Bytom area reached an elevation of 2.5-5.0 $\mathrm{m}$ and caused the formation of water marshes.

Disposing of the mining waste has a significance influence on the degradation of the environment. In the study area, there are two objects built of mining waste: an old railway bank in the western part, and a coal mining waste dump of burned and not burned waste in the northern site. On the dump itself, there is a sport object of Ośrodek Sportowo-Wypoczynkowy Rozbark Bytom). The researched area has been used as a place of illegal waste storage for several years. As a result, water table and surface waters were exposed to contact with hazardous effluents from disposed waste. The wastes and effluents were also hazardous for the soil cover. Natural surface soil cover has been transformed and degraded. In the study area a thick layer of anthropogenic material with different waste (rubble, roofing paper, synthetics, rubber, wood etc.) was discovered. The natural relief was transformed by of the rise of new hills and slopes built of waste. The degradation of the landscape influenced the aesthetics of the naturally rich and attractive area (Fig. 1). The negative impact on ecosystems was direct (e.g. habitat changes) as well as indirect, in the disturbance of the ecosystem function caused by the emission of pollution originating from waste.

\section{GEOLOGICAL COMPOSITION}

The lithological-stratigraphic description of the study area includes the Carboniferous, Triassic, Jurassic, Paleogene and Neogene layers. The layers older than the Carboniferous were not taken into consideration, because of their low significance for reclamation processes. The oldest sediments significant for the conducted work represent Carboniferous coal deposits, as well as accompanying rocks, associated with mining activity, which started more than 100 years ago in the region $(\mathrm{Ga}$ bzdyl 1999).

The Carboniferous orogeny was recognized in the study area from the coal seam 401 rudzkie beds, until the seam 621 of the porębskie beds. Geological data on these seams are important, because they form the only basis on which the composition of the mining wastes disposed in the area may be concluded. In this site, the following beds are distinguished: rudzkie, siodłowe and porębskie. The rudzkie beds occur in a form of alternating layers of sandstones, mudstones and siltstones with coal seams. The siodłowe beds are the most rich in coal Carboniferous layers and represent a complex of sandstones (sometimes also conglomerates) with an admixture of siltstones. The thickness of the coal seams in this area reaches 9-12 $\mathrm{m}$ - coal seam 510). The porębskie beds are characterized by the dominance of siltstones and mudstones over sandstones. The coal seams show large variability in thickness (Mgłosiek 1998).

The Triassic deposits on the whole area reach significant thickness. Particularly sedimentary rocks from Muschelkalk are well developed. They are represented by different types of dolomites with $\mathrm{Zn}-\mathrm{Pb}$ ores, comprised of ore minerals like sphalerite and galena. The thickness of carbonate rocks reaches $100 \mathrm{~m}$ (Gabzdyl 1999).

Under the carbonate layers, deposits of the Lower Triassic - Bundsandstein, of which the main part (ret) is represented by limestone, marls and dolomites with an admixture of silts, can be found. Lower and medium Bundsandstein is built of silts, sands, gravels and sandstones.

There is a thick layer of Miocene deposits, represented by marl silts, sands, sandstones, gypsum and tuffite.

The Holocene layers are represented by fluvial deposits - sands, clays and sandy clays with an admixture of humus.

\section{HYDROGEOLOGICAL AND HYDROLOGICAL CONDITIONS}

The hydrogeological conditions of the Upper Silesian Coal Basin are shaped by two factors: a natural factor (the influence of the geological composition of the region), as well as the mining factor. Groundwater flow occurs in the Neogene, Triassic and Carboniferous deposits. 
Water-bearing strata and the quality of groundwater depend on mining exploitation and mine drainage. The study area is situated in the zone of degraded groundwater covering a surface of ca. $177 \mathrm{~km}^{2}$. The mines located in the neighborhood of the Bytom-Rozbark are characterized by different inflows. Their intensity is connected with the hydraulic contact of the mining works with the water table in Triassic rocks. As a consequence of long-term mine drainage of the Bundsandstein, the water table has been dropping systematically (Kropka et al. 1998).

The long-term mining exploitation of $\mathrm{Zn}-\mathrm{Pb}$ ores and hard coal, in the neighborhood of the study area, has caused changes in the morphology of the ground surface. The mining subsidence and waste dumps leads to disturbances in natural water circulation. Changes in water conditions were caused, for example, by local inundation of the ground surface (Girczys 2002).

The study area designated for reclamation belongs to the catchment of the Bytomka River and is situated on the Bytomka's tributary - "Rów Graniczny". In the terrain depressions, three ponds linked together are to be found. There is no natural outflow from water reservoirs. Water which recharges the ponds comes from precipitation and infiltration from the "Rów Graniczny".

\section{MATERIALS AND METHODS}

Surface water samples were collected in July 2014 at 5 measurement points (Fig. 1):

P1 - control profile of "Rów Graniczny",

P2 - shallow pond overgrown with water plants,

P3 - shallow reservoir,

P4 - point at the outfall of the waste pipe,

P5 - pond.

The samples were collected from the surface layer, using a manual peristaltic pump connected to a filter press (equipped with a filter of $\varnothing 0.45 \mu \mathrm{m}$ ). Parameters such as $\mathrm{pH}$ and electrical conductivity were measured in the field, using a multifunctional meter - ELMETRON CX-742. Chemical analyses of chosen ions $\left(\mathrm{SO}_{4}^{2-}, \mathrm{Cl}^{-}, \mathrm{Ca}^{2+}, \mathrm{Mg}^{2+}, \mathrm{NO}_{3}^{-}\right.$, $\mathrm{NH}_{4}^{+}$) and total suspended solids were carried out in the laboratory of the Institute of Applied Geology, Silesian University of Technology in Gliwice, using a photometer Slandi LF-205.

\section{RESULTS}

In order to analyze water quality changes over the past five years, the results of water chemistry analysis carried out in July 2014 were compared with archival data from September 2009 (Studium wykonalności... 2009) (Tab. 1).

Tab. 1

Physicochemical parameters of analyzed water samples (points P1-P5)

\begin{tabular}{|l|c|c|c|c|c|c|c|c|c|c|}
\hline \multirow{2}{*}{\multicolumn{1}{|c|}{ Parameter }} & \multicolumn{2}{c|}{ P1 } & \multicolumn{2}{c|}{ P2 } & \multicolumn{2}{c|}{ P3 } & \multicolumn{3}{c|}{ P4 } & \multicolumn{2}{c|}{ P5 } \\
\cline { 2 - 12 } & $\mathbf{2 0 1 4}$ & $\mathbf{2 0 0 9}$ & $\mathbf{2 0 1 4}$ & $\mathbf{2 0 0 9}$ & $\mathbf{2 0 1 4}$ & $\mathbf{2 0 0 9}$ & $\mathbf{2 0 1 4}$ & $\mathbf{2 0 0 9}$ & $\mathbf{2 0 1 4}$ & $\mathbf{2 0 0 9}$ \\
\hline $\mathrm{pH}$ & 7.95 & 7.8 & 7.26 & 7.7 & 8.34 & 7.8 & 7.52 & 7.3 & 7.76 & 7.6 \\
\hline Conductivity $[\mu \mathrm{S} / \mathrm{cm}]$ & 7839 & 6500 & 3137 & 2800 & 2484 & 1860 & 8728 & 1040 & 6871 & 4300 \\
\hline $\mathrm{TSS}\left[\mathrm{mg} / \mathrm{dm}^{3}\right]$ & 59.8 & 59 & 49.2 & 90 & 48.4 & 5.2 & 73.6 & 26 & 57.8 & 166 \\
\hline $\mathrm{Cl}^{-}\left[\mathrm{mg} / \mathrm{dm}^{3}\right]$ & 1953 & 1300 & 411.6 & 380 & 384.3 & 1400 & 1365 & 1400 & 1008 & 1000 \\
\hline $\mathrm{SO}_{4}^{2-}\left[\mathrm{mg} / \mathrm{dm}^{3}\right]$ & 1648 & 1534 & 428 & - & 324 & - & 1354 & - & 1144 & - \\
\hline $\mathrm{NH}_{4}^{+}\left[\mathrm{mg} / \mathrm{dm}^{3}\right]$ & $<0.1$ & 0.16 & 0.4 & 0.54 & 0.4 & 0.44 & $<0.1$ & 1.1 & $<0.1$ & 2 \\
\hline $\mathrm{NO}_{3}^{-}\left[\mathrm{mg} / \mathrm{dm}^{3}\right]$ & 0.6 & 3.4 & $<0.5$ & $<0.23$ & $<0.5$ & $<0.23$ & 1.5 & $<0.23$ & 0.8 & $<0.23$ \\
\hline $\mathrm{Ca}^{2+}\left[\mathrm{mg} / \mathrm{dm}^{3}\right]$ & 212.4 & 226.3 & 92.2 & - & 60.1 & - & 188.4 & - & 148.3 & - \\
\hline $\mathrm{Mg}^{2+}\left[\mathrm{mg} / \mathrm{dm}^{3}\right]$ & 114.3 & 219.2 & 41.3 & - & 55.9 & - & 133.8 & - & 109.4 & - \\
\hline
\end{tabular}

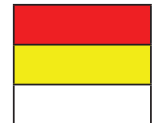

third and below water quality class

second water quality class

first water quality class (Journal of Laws 2014, item 1482) 
Comparing the results of our own study with the archival data from 2009, it was found that in both cases, the surface waters were characterized as weakly basic. In the samples collected at points P1, P3, P4 and P5 in 2014, a slight pH increase was observed compared to 2009. In the water sample from $\mathrm{P} 2$, a slight $\mathrm{pH}$ decrease occurred during this time interval. In general, the differences in $\mathrm{pH}$ values are so low, that it is difficult to identify any trends. With regard to the environmental standards for surface water bodies, in all the samples collected in 2009 and 2014, the pH values of the analyzed waters show that they can be classified in the first quality class (Journal of Laws 2014, item 1482).

Electrical conductivity is one of the commonly measured water parameters, which correlates with the amount of dissolved solids in the water. In all samples collected in 2014, a significant increase of electrical conductivity was observed, compared to the values in 2009 (Fig. 2). The most significant difference was noticed in the case of a sample taken in the point $\mathrm{P} 4$, where the conductivity increased more than 8 times. Point $\mathrm{P} 4$ is located at the outlet of the waste pipe and this huge increased may be caused by inflow of waste water with an elevated concentration of compounds affecting the conductivity, probably sulphates. However, this correlation is difficult to be proved, because content of sulphates was measured only in 2014, and the differences in the concentration of this compound between the analyzed years cannot be presented. With the exception of the sample collected at point P4 in 2009, in all other samples the conductivity significantly exceeded the level of $1,500 \mu \mathrm{S} / \mathrm{cm}$ (the limit for the second quality class of surface water).

In the case of total suspended solids (TSS), an increase was observed in water samples taken in 2014 at points $\mathrm{P} 1, \mathrm{P} 3$, and $\mathrm{P} 4$, while a decrease was observed in points P2 and P5, compared to 2009 (Fig. 3). Due to the total suspended solids content, water samples collected in the current year at points $\mathrm{P} 2$ and $\mathrm{P} 3$ are qualified as second water quality class. Samples taken at points $\mathrm{P} 1, \mathrm{P} 4$ and $\mathrm{P} 5$ can be classified as third quality and below.

It was found, that in the water samples collected at points $\mathrm{P} 1, \mathrm{P} 2$ and $\mathrm{P} 5$, the concentration of chloride increased in 2014, compared to their levels in 2009 (Fig. 4). The largest differences were noticed in a sample taken at point $\mathrm{P} 1$, where chloride concentration increased by over $30 \%$. At point $\mathrm{P} 4$, a slight decrease of chloride concentration was observed. At point $\mathrm{P} 3$, this decline was noticeable, by a factor of more than 3. At the all sampled points, during both analyzed years, the limit of chloride for second water quality class $(300 \mathrm{mg} / \mathrm{L})$ was exceeded.

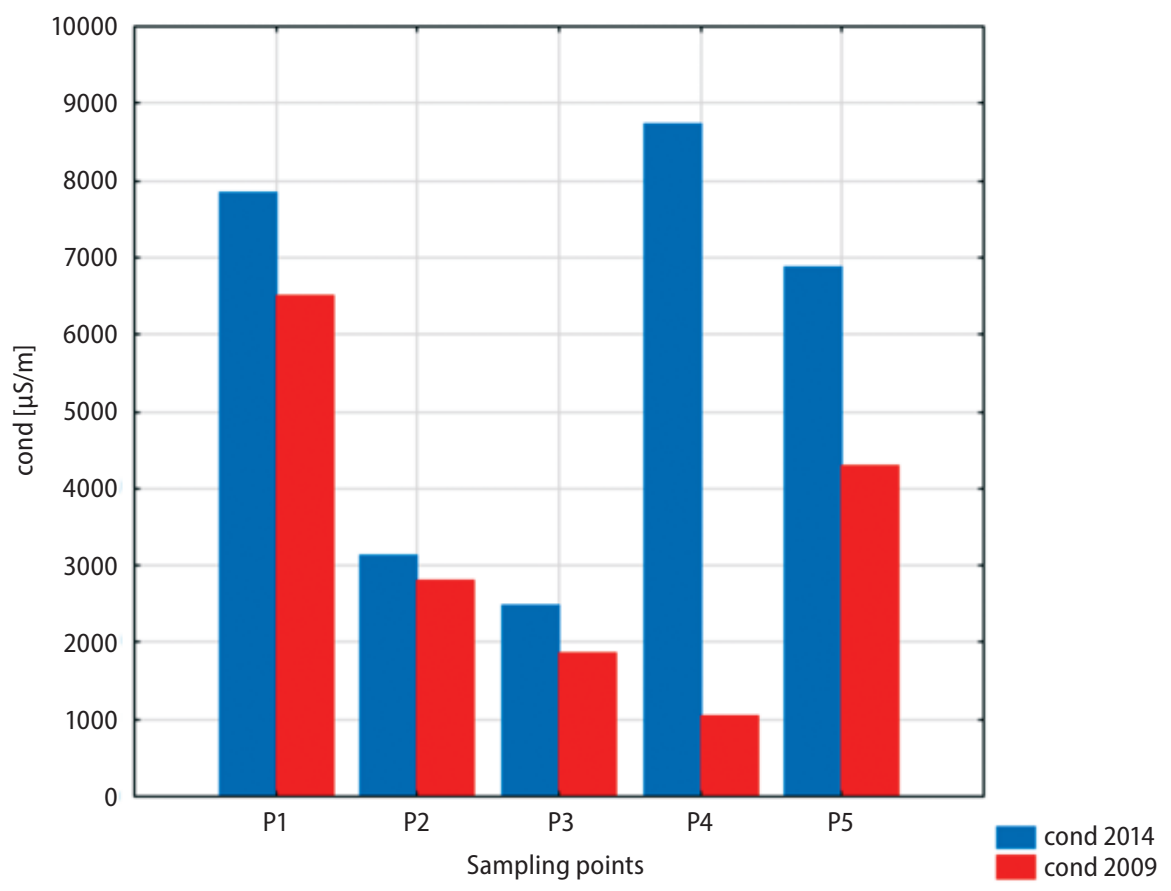

Fig. 2. Electrical conductivity of analyzed waters in 2009 and in 2014 


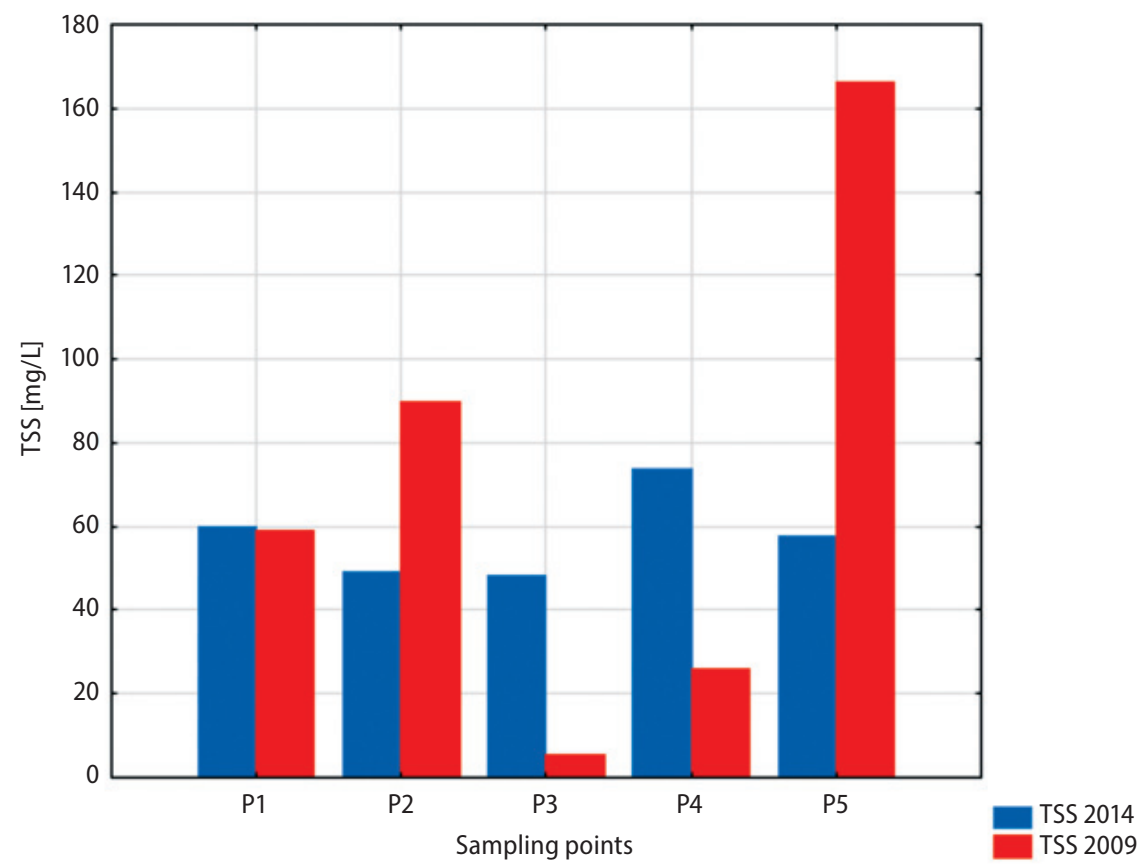

Fig. 3. Total suspended solids (TSS) of waters analyzed in 2009 and in 2014

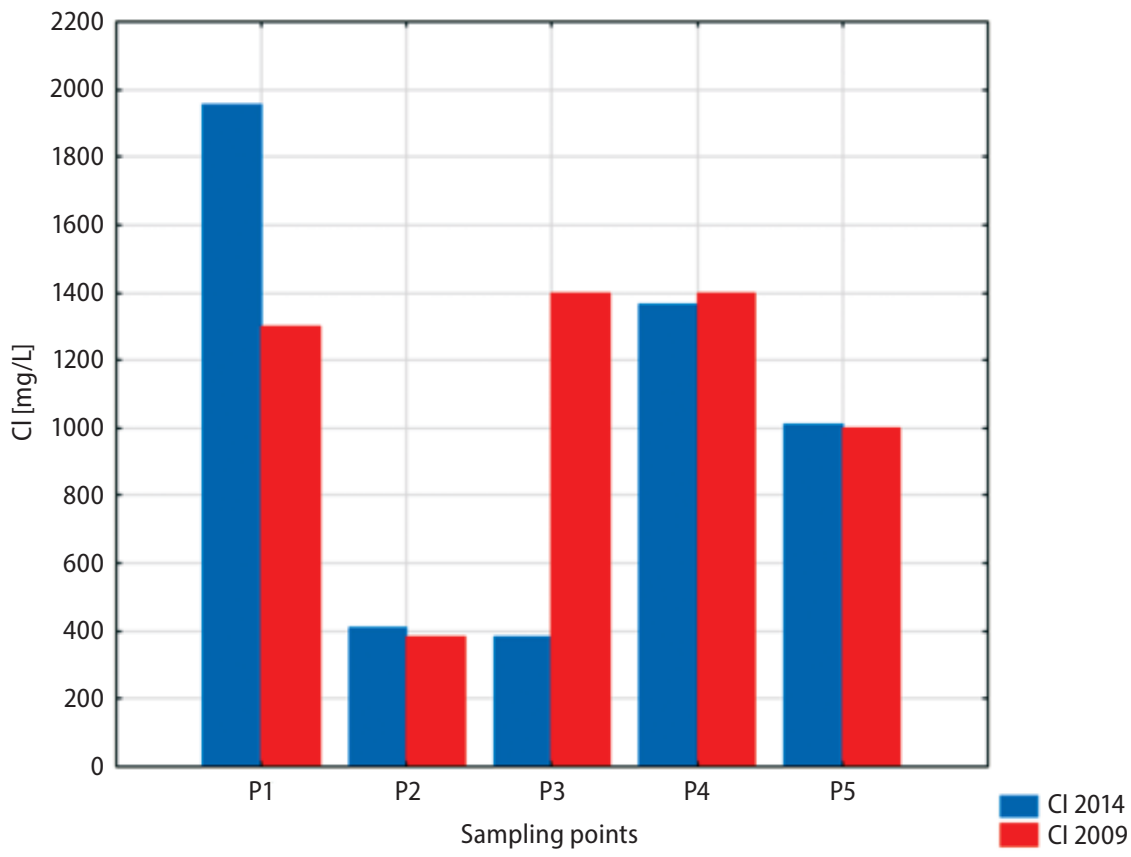

Fig. 4. Chloride concentration in analyzed waters in 2009 and 2014

In the case of sulphate, it is impossible to carry out a comparative analysis of the changes in the concentration levels that have occurred within the five years, because in 2009, sulphates were measured only in waters collected at point P1. An increase was observed at this point (by less than $10 \%)$ over the analyzed period of time. In the all samples collected in 2014, an abnormal concentration of sulphate were found, especially at points P1, P4 and P5, where concentrations significantly exceeded the limit for the second quality class of surface water $(250 \mathrm{mg} / \mathrm{L})$.

In all of the analyzed water samples collected in 2014, a decrease of ammonium was noticeable, 
compared with its values in 2009. Taking into consideration the concentration of ammonium, analyzed surface waters belong to the first water quality class.

It was found, that in the water samples collected in 2014 at points P4 and P5, the concentrations of nitrates increased, while at point P1 it decreased considerably, compared to the levels in 2009. In the case of samples taken at points $\mathrm{P} 2$ and $\mathrm{P} 3$, it is impossible to determine the changing trend of this parameter during the analyzed period of time, because the concentrations of nitrates in both samples were well below their detection limit. Due to the low concentration of nitrates, the analyzed surface waters qualify as first water quality class.

The determination of calcium and magnesium concentrations was conducted in 2009 , only at point P1. Here, it was found, that over the five years period, there was a slight decrease in the concentration of calcium and a nearly double decrease in the concentration of magnesium. Due to the concentration of calcium, the water collected in 2014, at point P1 is classified as third and below water quality class. Waters from points P2 and P3 are classified as first water quality class, and waters collected at points $\mathrm{P} 4$ and $\mathrm{P} 5$, as the second water quality class. Taking into account the concentration of magnesium, waters collected at points $\mathrm{P} 1$, $\mathrm{P} 4$ and $\mathrm{P} 5$ are classified as third and below water quality class, water sampled at point $\mathrm{P} 2$, as a first water quality class, and water taken at point $\mathrm{P} 3$, as second water quality class.

\section{DISCUSSION}

Based on the results of analyses and archival data, it was found that both in 2009 and 2014, the largest degree of water pollution was observed in "Rów Graniczny". This situation is a result of the contaminated water being discharged from the mine "KWK Centrum". The contribution of mine water is much higher than the volume of the natural outflow from the source. Further along the course of "Rów Graniczny", treated wastewater from the mechanical-biological treatment plant "Rozbark" is also collected. Abnormal concentrations of chloride, sulphate and high values of electrical conductivity are a consequence of these discharges. The analyses clearly indicate a high degree of contamination of the water from "Rów Graniczny". It is recommended that measures are taken to reduce the amount of pollution and improve the quality of the water.

Among the samples analyzed, surface water taken at points $\mathrm{P} 2$ and $\mathrm{P} 3$ (shallow ponds) is characterized by the smallest degree of pollution. However, these waters are also classified as a third and below water quality class because of the exceeding the permissible values of chloride concentration and other parameters.

The results of the analysis indicated that the water chemistry is a consequence of mine drainage. Water from the reservoirs is characterized by an elevated concentrations of sulphate, increased values of electrical conductivity and total suspended solids - typical parameters of contaminated drainage water.

Based on the results of the study, in relation to environmental standards for surface water bodies, it was found that all surface water samples collected in 2014 qualify as a third and below water quality class. This is due to the fact that, in each sample, at least two parameters used in the analysis of water were exceeded. For samples collected in 2009, only water from point P2 can be classified as a second water quality class. Water from the remaining points is classified as a third and below water quality class.

\section{CONLUSIONS}

Comparative analysis shows that in the last five years, there has been no improvement in the quality of the analyzed surface water, and their deterioration in quality was noticeable. In all samples, the permissible concentration of chlorides and sulphates, and in most samples, the values of electrical conductivity and total suspended solids were exceeded. On this basis, it seems that the waste dumps located in the analyzed area have not been completely leached yet, which causes additional pollution and the migration of pollutants to the surface water.

It can be assumed that the self-purification processes occuring in the aquatic environment are so slow, that they do not lead to perceptibly natural elimination of the pollutants. These processes will probably last several decades at the least. 


\section{REFERENCES}

Gabzdyl W., 1999. Geologia złóż. Series: Skrypty Uczelniane - Politechnika Śląska im. Wincentego Pstrowskiego, 2163, Wyd. Politechniki Śląskiej, Gliwice.

Girczys J. \& Sobik-Szołtysek J., 2002. Odpady przemysłu cynkowo-ołowiowego. Series: Monografie - Politechnika Częstochowska, 87, Wyd. Politechniki Częstochowskiej, Częstochowa.

Kondracki J., 2000. Geografia regionalna Polski. Wyd. Nauk. PWN, Warszawa.

Kropka J., Kowalczyk A. \& Rubin K., 1998. Mapa hydrogeologiczna Polski w skali 1:50 000. Arkusz Bytom. Państwowy Instytut Geologiczny, Warszawa.

Labus K. \& Skoczyńska S., 2013. Origin of sulphates in the post-mining lakes in the eastern part of Muskau Arch (Polish-German borderland). Geological Quarterly, 57, 3, 561-566.

Mgłosiek J., 1998. Zróżnicowanie jakości wegla niecki bytomskiej na przykładzie pokładów 407/1 i 507 w obszarze górniczym KWK Rozbark. Archiwum Instytutu Geologii Stosowanej.

Pluta I., 2004. Kwaśne wody w kopalniach południowo-zachodniego obszaru Górnośląskiego Zagłębia Węglowego. Przegląd Górniczy, 2, 20-23.
Razowska L., 2001. Changes of groundwater chemistry within the flooded iron mines area in the Czestochowa Region (Southern Poland). Journal of Hydrology, 244, 17-32.

Rozporzadzenie Ministra Środowiska $z$ dnia 22 października 2014 r. w sprawie sposobu klasyfikacji stanu jednolitych części wód powierzchniowych oraz środowiskowych norm jakości dla substancji priorytetowych. Dz. U. 2014, poz. 1482 [Journal of Laws 2014, item 1482].

Studium wykonalności, karta informacyjna projektu, specyfikacja techniczna oraz dokumentacja techniczna na potrzeby wniosku o dofinansowanie w ramach Programu Rozwoju Subregionu Centralnego Regionalnego Programu Operacyjnego „Rekultywacja zdegradowanych zalewisk wodnych w Bytomiu", 2009, Bytom.

Szczepańska J., 1990. Zwałowiska odpadów węgla kamiennego jako ogniska zanieczyszczeń środowiska wodnego. Series: Zeszyty Naukowe Akademii Górniczo-Hutniczej im. Stanisława Staszica. Geologia, 35, AGH, Kraków.

Twardowska I., Szczepańska J. \& Witczak S., 1988. Wpływ odpadów górnictwa wegla kamiennego na środowisko wodne: ocena zagrożenia, prognozowanie, zapobieganie. Series: Prace i Studia - Polska Akademia Nauk. Instytut Podstaw Inżynierii Środowiska, 35, Zakład Narodowy im. Ossolińskich, Wrocław. 